Y. SUN ${ }^{1}$, X. CUI ${ }^{2}$, Sh. YIN ${ }^{3}$, D. YU ${ }^{3}$, Sh. $\mathrm{LI}^{4}$, W. ZHANG ${ }^{3}$, and J. ZHAO ${ }^{3}$

\title{
EFFECTS OF SCORPION VENOM HEAT-RESISTANT PROTEIN ON SEIZURE BEHAVIOR AND EXPRESSION OF PROENKEPHALIN IN RATS WITH KAINATE- INDUCED EPILEPSY
}

Received November 22, 2012.

Scorpion venom is a traditional antiepileptic medicine in Asia. We examined the effects of scorpion venom heat-resistant protein (SVHRP) on seizure behavior of rats with kainate-induced epilepsy and expression of proenkephalin (pENK) in their hippocampus. Subcutaneous injections of convulsive doses of kainic acid (KA, $10 \mathrm{mg} / \mathrm{kg}$ ) evoked acute epileptic seizures; the intensity of such seizures was measured after subsequent injections of lower (subthreshold in the norm) doses of KA $(5 \mathrm{mg} / \mathrm{kg})$. Scorpion venom heat-resistant protein in a dose of $125 \mu \mathrm{g} / \mathrm{kg}$ was given in a part of the animals through i.p. injections daily during 10 days; rats of the control groups were injected with normal saline. Behavioral indices were measured, and the hippocampus was taken for pENK mRNA estimation by RTPCR analysis. The mean behavioral score of seizure sensitivity in the SVHRP-treated group was smaller significantly $(P<0.05)$ compared to that in the control group $(1.19$ vs 2.93$)$. The pENK mRNA level was dramatically greater in hippocampal neurons of KA-treated rats with a high seizure sensitivity, while in the SVHRP-treated group the respective index was significantly lower. Thus, SVHRP inhibits behavior seizures in epilepsy and reverses the abnormally increased pENK mRNA in hippocampal neurons of such animals.

Keywords: scorpion venom heat-resistant protein, proenkephalin, kainate-induced epilepsy.

\section{INTRODUCTION}

Epilepsy is a widespread neurodegenerative disease; it can become a stubborn and intractable disease in clinics due to the formation of abnormally high epilepsy sensitivity. It was shown that opioid peptides may be significantly involved in the mechanisms of underlying formation of epilepsy sensitivity. The content of enkephalin (ENK) is the highest among opioid peptides expressed widely in the brain.

Scorpion venom is a traditional antiepileptic medicine in Asia, and scorpion venom heat-resistant protein (SVHRP) extracted via a special process is the major component having antiepileptic activity.

\footnotetext{
${ }^{1}$ Functional Lab, Dalian Medical University, Dalian, China.

${ }^{2}$ Seven-year-program medical student, Dalian Medical University, Dalian, China.

${ }^{3}$ Department of Physiology, Dalian Medical University, Dalian, China.

${ }^{4}$ Medical postgraduate student, Dalian Medical University, Dalian, China.

Correspondence should be addressed to Jie Zhao

(e-mail: dlyipingsun@163.com)
}

In this study, we explored the effects of SVHRP on seizure behavior of rats with experimentally induced epilepsy and expression of proenkephalin (pENK) in their hippocampus.

\section{METHODS}

Experimental Materials and Grouping. Healthy male Sprague-Dawley rats weighing 180 to $220 \mathrm{~g}$ were obtained from the Experimental Animal Center of the Dalian Medical University. Scorpion venom was collected from the Buthus martensii Karsch through a special process developed in Yiyang Town, Henan Province, China (National Invention Patent No. ZL01106166.9). Scorpion venom heat-resistant protein was partially purified using an ultrafilter. Kainate (kainic acid, KA) was purchased from Sigma (USA); RT-PCR kit, PCR primers, and internal standards were from Takara Biotechnology Co. Ltd. (Dalian, China).

All tested animals were randomly divided into two groups. Subcutaneous injections of KA in a convulsive 


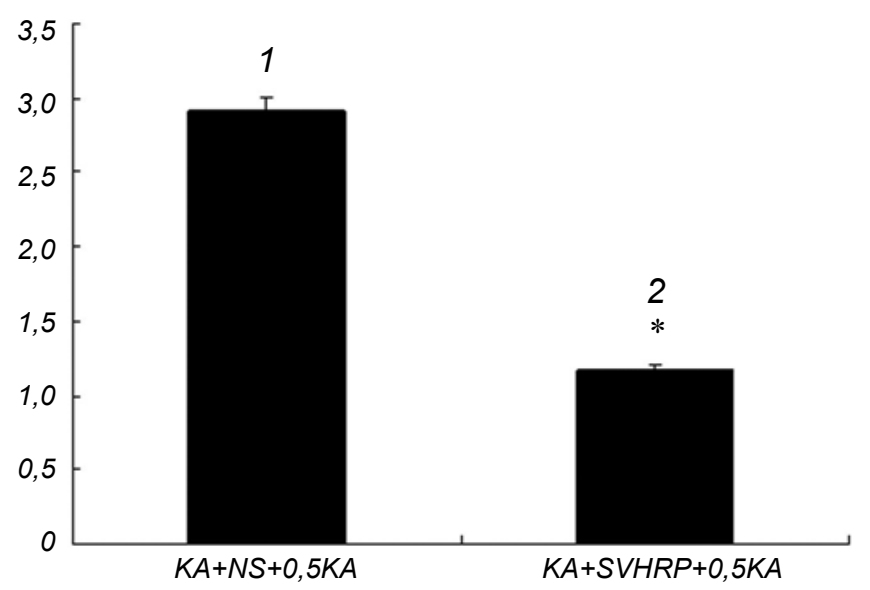

F i g. 1. Mean seizure susceptibility behavior scores (vertical scale) of kainic acid (KA)-treated rats. 1 and 2) Model (KA+NS+0.5KA) and therapy (KA+SVHRP+0.5KA) groups, respectively. $* P<0.05$ vs the model group.

Р и с. 1. Середні оцінки (поведінкові бали) судомної чутливості (вертикальна шкала) у щурів, котрі отримували каїнову кислоту.

dose $(10 \mathrm{mg} / \mathrm{kg})$ were conducted to induce acute epileptic seizures; animals of another group were injected with equal volumes of normal saline (NS). Normal saline and SVHRP $(125 \mu \mathrm{g} / \mathrm{kg})$ were given for two groups of rats through i.p. injections daily for a period of 10 days. Subcutaneous injections of a subthreshold (in the norm) dose of KA (5 mg/ $\mathrm{kg}$ ) or saline were then given in these two groups. Thus, four groups of animals were formed, (i) model group (KA+NS+0.5KA), (ii) therapy group $(\mathrm{KA}+\mathrm{SVHRP}+0.5 \mathrm{KA})$, (iii) blank control group $(\mathrm{NS}+\mathrm{NS}+0.5 \mathrm{NS}$ ), and (iv) negative control group $(\mathrm{NS}+\mathrm{SVHRP}+0.5 \mathrm{NS})$. The epilepsy susceptibility was measured in these groups according to the seizure score.

Behavior Examination. The seizures were scored using a modified Racine scale. Chewing, head nodding, unilateral forelimb clonus, rearing with bilateral forelimb clonus, and rearing with bilateral forelimb clonus and falling back were recorded as grades 1 to 5 , respectively.

Proenkephalin mRNA by RT-PCR Analysis. Reverse transcription was conducted after the extraction of total RNA. The reaction mix at a total volume of $20 \mu \mathrm{l}$ included $2.0 \mu 110 \times$ RNA PCR buffer, $2.0 \mu \mathrm{l}$ dNTP mixture, $0.5 \mu \mathrm{l}$ RNase inhibitor, $1.0 \mu \mathrm{l}$ AMV reverse transcriptase, $8.5 \mu 1$ RNase-free $\mathrm{dH}_{2} \mathrm{O}$, $1.0 \mu \mathrm{l}(=1 \mu \mathrm{g})$ of RNA samples, $1.0 \mu \mathrm{l}$ random primer, and $4.0 \mu \mathrm{l} \mathrm{MgC1}_{2}$. Reaction conditions were the following: $+30^{\circ} \mathrm{C}$ for $10 \mathrm{~min},+42^{\circ} \mathrm{C}$ for $60 \mathrm{~min},+99^{\circ} \mathrm{C}$ for $5 \mathrm{~min}$, and $+5^{\circ} \mathrm{C}$ for $5 \mathrm{~min}$. PCR amplification: the cDNA was used as a formwork for PCR amplification in a total volume of $25 \mu \mathrm{l}$, including $2.0 \mu 1 \quad 10 \times$ RNA PCR buffer, $14.875 \mu \mathrm{l}$ RNase-free $\mathrm{dH}_{2} \mathrm{O}, 0.125 \mu \mathrm{l}$ Taq DNA polymerase, $5.0 \mu \mathrm{l}$ reverse transcription product, $0.75 \mu \mathrm{l}$ of $40 \mu \mathrm{M} \mathrm{L}-13$ 3' 5 primer, $0.75 \mu \mathrm{l}$ of $40 \mu \mathrm{M} \mathrm{L}-13^{\prime}$ primer, and $1.5 \mu \mathrm{MgC} 1_{2}$. Reaction conditions were the following: $+94^{\circ} \mathrm{C}$ for $45 \mathrm{sec}$, $+60^{\circ} \mathrm{C}$ for $45 \mathrm{sec}$, and $72^{\circ} \mathrm{C}$ for $45 \mathrm{sec}$ by 31 cycles; terminal extension $+72^{\circ} \mathrm{C}$ for $5 \mathrm{~min} ; 1.5 \%$ agarose gel electrophoresis was used for testing PCR products. Quantitative analysis of the average absorbance of PCR products was measured by a gel analysis system; statistical analysis was carried out using standard software. The primer sequence was the following:

pENK f 5'-GTCCACCATTGGTTCAGAAGG -3'; r 5'-ACCGCATAAAGCCTCCGTATC-3'.

\section{RESULTS}

Seizure Susceptibility Testing. In the model $(\mathrm{KA}+\mathrm{NS}+0.5 \mathrm{KA})$ group, 11 rats developed seizures at grade 3 or above, and one animal developed grade 2 . In 12 rats of the therapy (KA+SVHRP $+0.5 \mathrm{KA})$ group, two animals showed grade 3 or above, three animals showed grade 2, two rats showed grade 1, and the remaining five showed only occasional chewing or no seizures. Thus, the seizure susceptibility behavior score in the therapy group was significantly lower $(P<0.05)$ than that in the model group: the mean score in the therapy group corresponded only to $40.0 \%$ of the respective index in the model group (Fig. 1).

RT-PCR Results of pENK mRNA. Kainic acidtreated rats with a high seizure sensitivity showed strongly upregulated pENK mRNA in hippocampal neurons compared with the other three groups, and differences were statistically significant $(P<0.01)$. The expression of pENK mRNA in hippocampal neurons of rats of the therapy group was significantly lower $(P<0.05)$ than that in the control group (Figs. 2 and 3 ).

\section{DISCUSSION}

Epilepsy is one of the most widespread neurological disorders. In adults with temporal lobe epilepsy (TLE), complex partial seizures have the poorest 

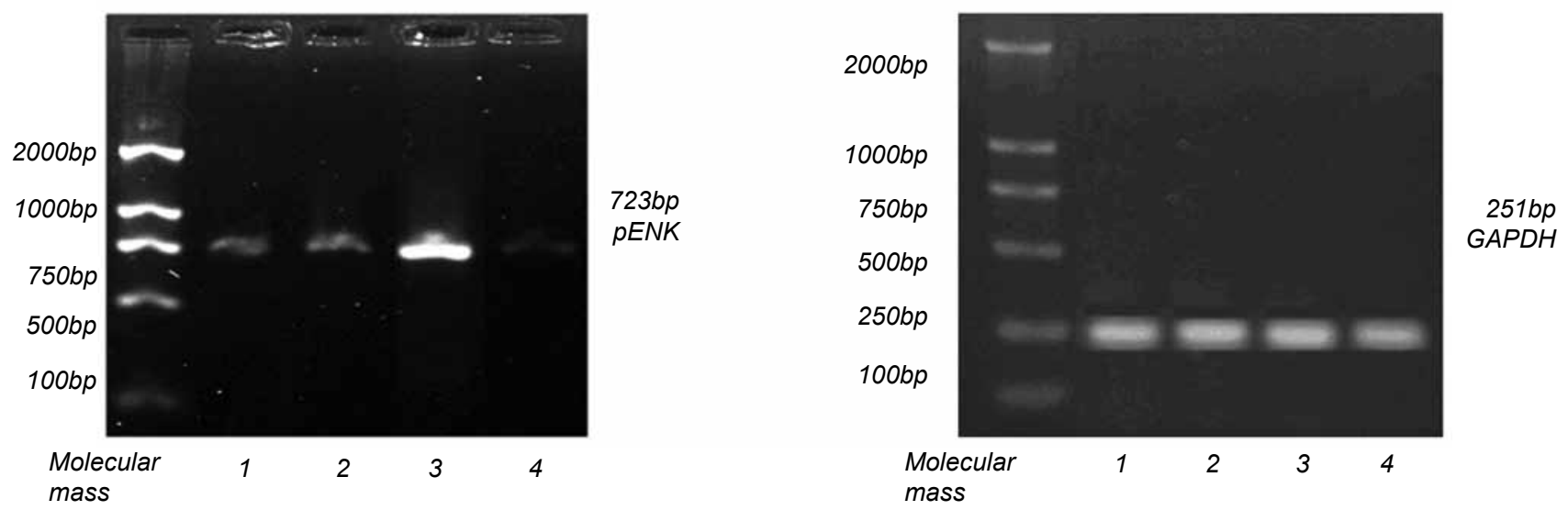

F i g. 2. Expression of proenkephalin (pENK) mRNA (vertical scale, OD pENK/OD GAGPH) in hippocampal neurons of the rats. 1-4) Animal groups: blank control group, NS+NS+0.5NS, no seizure (1), negative control group, NS+ SVHRP $+0.5 \mathrm{NS}$, no seizure (2), model group, $\mathrm{KA}+\mathrm{NS}+0.5 \mathrm{KA}$, seizure (3), and therapy group, $\mathrm{KA}+\mathrm{SVHRP}+0.5 \mathrm{KA}(4)$.

Р и с. 2. Експресія мРНК проенкефаліну (пЕНК; вертикальна шкала, OD pENK/OD GAGPH) у нейронах гіпокампа щурів.

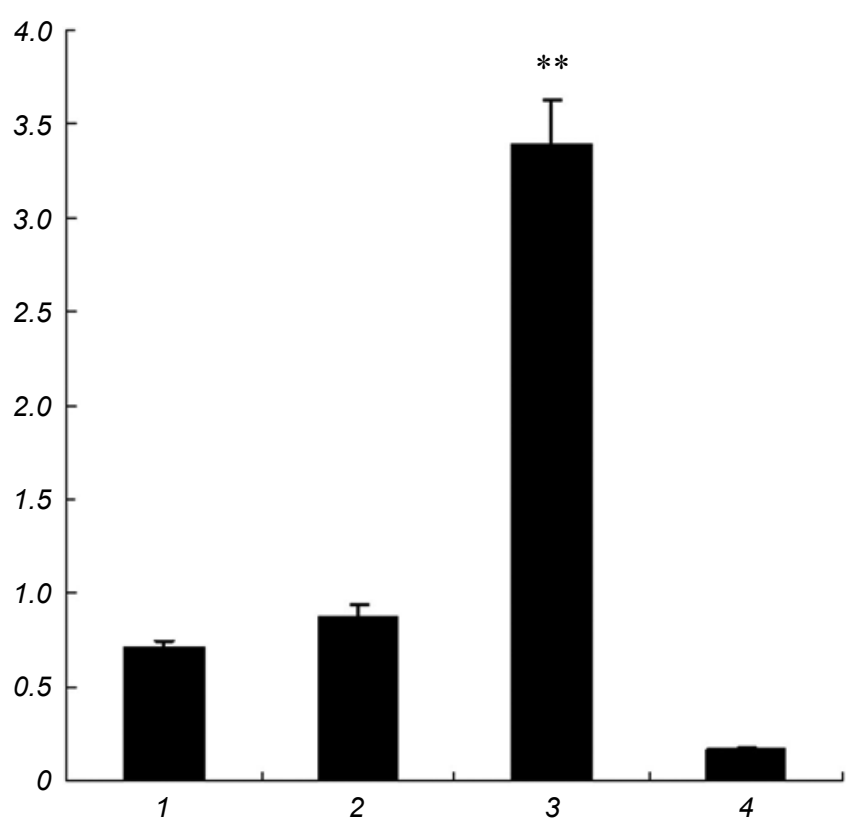

F i g. 3. The OD pENK/OD in hippocampal neurons of the rats. $* * P<0.01$ vs the control groups and therapy group.

Р и с. 3. OD pENK/OD у нейронах гіпокампа щурів.

prognosis among all types of seizures; about 60 $70 \%$ of all patients of such a group have intractable seizures. It should be recognized that the mechanisms of TLE are still unclear. Kainic acid is a structural analog of an excitatory amino acid neurotransmitter, glutamate. Single systemic injections of a convulsive dose of KA result in the development of the limbic status epilepticus with a high seizure susceptibility [1]. Therefore, the KA-induced epilepsy model has been widely used to study human TLE [2].

Enkephalin (ENK) is one of the important endogenous opioid peptides first isolated in 1975 [3]. Hong first proved by radioimmunoassay that the content of ENK in the hippocampus increases after treatment with the lowest dose of KA inducing acute seizures [4, 5]. Later on, several studies suggested that the expression of ENK and its precursor pENK mRNA in the hippocampus demonstrate rather high values in a variety of different types of animal models of TLE, including the KA model $[2,6]$, penicillininduced epilepsy model, model based on electriclight or chemical kindling, that based on electrical stimulation of the hippocampal perforant pathway, and other animal models [7, 8]. The discharges and seizures in abnormal EEGs were detected after intracerebroventricular injections of ENK. In addition, the ENK levels in the cerebrospinal fluid of epilepsy patients were also found to be increased significantly $[9,10]$. A few studies indicated that ENK is also involved in the formation of high epilepsy sensitivity, and long-lasting expression of pENK mRNA was observed in the hippocampus of susceptible animals with epileptic seizures [11]. However, it remains unknown whether the alternation of the ENK level is one of the reasons for the development of epilepsy, or if it is a consequence of this pathology. 
Our study suggests that SVHRP strongly inhibits the formation of the epilepsy sensitivity, and it also reduces the expression of pENK mRNA in the hippocampus of sensitive animals in the model of epilepsy. Thus, SVHRP-related inhibition of the sensitivity with respect to epilepsy correlates with normalization of abnormal overexpression of ENK in one of the brain structures whose role in the development of epilepsy is crucial. These facts may provide a clue for understanding the mechanism of TLE.

The experiments were carried out in accordance with the internationally accepted and institutional ethical norms related to the studies on vertebrate animals.

The authors, Y. Sun, X. Cui, Sh. Yin, D. Yu, Sh. Li, W. Zhang, and J. Zhao, have no conflict of interests.

This work was supported by grants from the National Natural Science Foundation of China, No. 31171037/c090202, the Liaoning Province Education Department Scientific Technological Research, LS2010057, and the Doctoral Fund of the Ministry of Education of China for Youth Scholars (20092105120006).

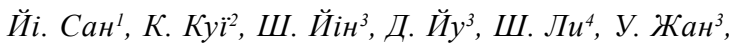
Дж. Жао

\section{ВПЛИВ ТЕРМОСТІЙКОГО ПРОТЕЇНУ 3 ОТРУ- ТИ СКОРПІОНА НА СУДОРОЖНУ ПОВЕДІНКУ ТА ЕКСПРЕСІЮ ПРОЕНКЕФАЛІНУ У ЩУРІВ З ВИКЛИКА- НОЮ КАЇНАТОМ ЕПІЛЕПСІЕЮ}

\footnotetext{
${ }^{1}$ Функціональна лабораторія, Далянський медичний університет, Далянь (Китай).

${ }^{2}$ Студент-медик, Далянський медичний університет, Далянь (Китай).

${ }^{3}$ Відділ фізіології, Далянський медичний університет, Далянь (Китай).

${ }^{4}$ Аспірант-медик, Далянський медичний університет, Далянь (Китай).

$\mathrm{P}$ е $з$ ю м е
}

Отрута скорпіона є традиційним антиепілептичним терапевтичним засобом в Азії. Ми вивчали вплив термостійкого протеїну з отрути скорпіона (ТСПОС) на судорожну поведінку щурів з викликаною каїнатом епілепсією та на експресію проенкефаліну (пЕНК) у їх гіпокампі. Підшкірні ін'єкції «конвульсивних» доз каїнової кислоти (КК, 10 мг/кг) призводили до розвитку гострих епілептичних судом; інтенсивність таких судом вимірювали після наступних ін'єкцій КК (5 мг/кг, підпорогова доза в нормі). Частина тварин отри- мувала ТСПОС у дозі 125 мкг/кг шляхом внутрішньоочеревинних ін'єкцій щоденно протягом 10 днів; щурам контрольної групи вводили фізіологічний розчин. Вимірювали поведінкові показники; гіпокамп ізолювали для подальшої оцінки пЕНК мРНК з використанням RT-PCR-аналізу. Усереднені поведінкові показники судомної чутливості в групі тварин, котрі отримували ТСПОС, були істотно нижче $(P<$ $<0.05)$ таких у контрольній групі (1.19 проти 2.93). У нейронах гіпокампа щурів із високою судомною чутливістю, котрі отримували КК, рівень пЕНК мРНК був істотно вищим, тоді як у тварин з ін'єкціями ТСПОС відповідний показник був значно нижчим. Отже, ТСПОС гальмує поведінкові судоми при епілепсії та різко зменшує аномально збільшений рівень пЕНК мРНК у нейронах гіпокампа таких тварин.

\section{REFERENCES}

1. S. M. Yin, Z. Guan, Y. Tang, et al., “Abnormal expression of epilepsy-related gene ERG1/NSF in the spontaneous recurrentseizure rats with spatial learning memory deficits induced by kainic acid," Brain Res., 1053, 195-202 (2005).

2. M. Obeid, J. Frank, M. Medina, et al., "Neuroprotective effects of leptin following kainic acid-induced status epilepticus," Epilepsy Behav., 19, No. 3, 278-283 (2010).

3. J. S. Han, Principles of Neuroscience [in Chinese], Peking Univ. Press, Beijing (1999).

4. J. S. Hong, P. L. Wood, and J. C. Ggillin, "Changes of hippocampal met-enkephalin content after recurrent motor seizures," Nature, 285, No. 5762, 231-232 (1980).

5. J. S. Hong, J. F. McGinty, P. H. Lee, et al., "Relationship between hippocampal opioid peptides and seizures," Prog. Neurobiol., 40, No. 4, 507-528 (1993).

6. Y. H. Kim, S. S. Choi, J. K. Lee, et al., "Possible roles of JNK pathway in the regulation of hippocampal proenkephalin and immediate early gene expression induced by kainic acid," Mol. Cells, 11, No. 2, 144-150 (2001).

7. R. J. Lee, J. S. Hong, J. F. McGinty, et al., "Increased enkephalin and dynorphin immunoreactivity in the hippocampus of seizure-sensitive Mongolian gerbils," Brain Res., 401, No. 2, 353-358 (1987).

8. M. E. Moneta and V. Höllt, "Perforant path kindling induces differential alterations in the mRNA levels coding for prodynorphin and proenkephalin in the rat hippocampus," Neurosci. Lett., 110, No. 3, 273-278 (1990).

9. L. Chen, "Enkephalin, neuropeptide Y, NSE and epilepsy," Fore Med. Inform., 25, No. 1, 7-10 (2004).

10. C. J. Schindler, R. Slamberová, A. Rimanyczy, et al., "Fieldspecific changes in hippocampal opioid mRNA, peptides, and receptors due to prenatal morphine exposure in adult male rats," Neuroscience, 126, No. 2, 355-364 (2004).

11. H. S. Noh, D. W. Kim, S. S. Kang, et al., "Ketogenic diet decreases the level of proenkephalin mRNA induced by kainic acid in the mouse hippocampus," Neurosci. Lett., 395, No. 1 87-92 (2006). 